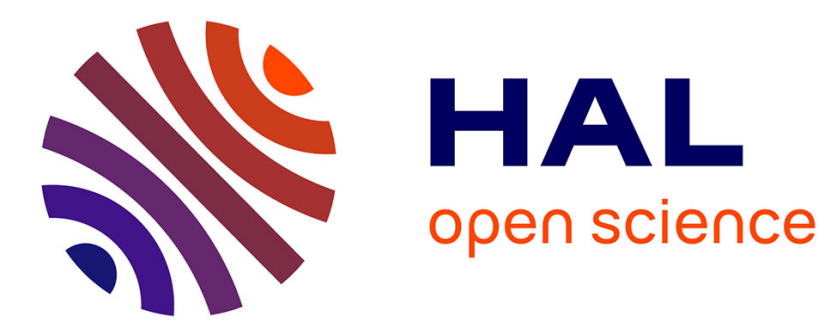

\title{
Cockroaches and tomatoes investigated by laser photoacoustics
}

F. Bijnen, H. de Vries, F. Harren, J. Reuss

\section{To cite this version:}

F. Bijnen, H. de Vries, F. Harren, J. Reuss. Cockroaches and tomatoes investigated by laser photoacoustics. Journal de Physique IV Proceedings, 1994, 04 (C7), pp.C7-435-C7-443. 10.1051/jp4:19947102 . jpa-00253154

\section{HAL Id: jpa-00253154 https://hal.science/jpa-00253154}

Submitted on 1 Jan 1994

HAL is a multi-disciplinary open access archive for the deposit and dissemination of scientific research documents, whether they are published or not. The documents may come from teaching and research institutions in France or abroad, or from public or private research centers.
L'archive ouverte pluridisciplinaire HAL, est destinée au dépôt et à la diffusion de documents scientifiques de niveau recherche, publiés ou non, émanant des établissements d'enseignement et de recherche français ou étrangers, des laboratoires publics ou privés. 


\title{
Cockroaches and tomatoes investigated by laser photoacoustics
}

\author{
F.G.C. Bijnen, H.S.M. de Vries, F.J.M. Harren and J. Reuss \\ Department of Molecular and Laser Physics, University of Nijmegen, Toernooiveld, 6525 ED Nijmegen, \\ The Netherlands
}

\begin{abstract}
Technical details of two sensitive gas photoacoustic experimental systems based on the use of tunable $\mathrm{CO}$ (cryogenic) and waveguide $\mathrm{CO}_{2}$ lasers as radiation sources are given and their application to specimens of biological origin (cockroaches and tomatoes) described. The results obtained present feasibility and flexibility of this technique in studies requiring high stability and fast response over extended measuring intervals.
\end{abstract}

\section{INTRODUCTION}

In the past years laser photoacoustic (PA) spectroscopy capable of detecting gas concentrations at the trace level, has also been recognized as an important tool for studies of biological processes. Very high sensitivity and fast time response (10 seconds) in on-stream analysis have already been achieved with powerful and line tunable $\mathrm{CO}$ and $\mathrm{CO}_{2}$ lasers $[1,2]$.

Such short response times are of interest in studies that include metabolic changes in plants exposed to external stress factors. For example, small concentrations of ethylene, the only gaseous plant hormone, were found to influence wilting, supergrowth or germinating effects in plant material. Due to its high sensitivity laser PA spectroscopy enables practically on-line measurements, i.e. monitoring the response of plant to a variety of ambient conditions without a need to accumulate (concentrate) gases in a space adjacent to plant tissue; accumulation would change and falsify the plant response. The existence of some degree of spectral coincidence between a specific $\left(\mathrm{CO}\right.$ or $\mathrm{CO}_{2}$ lasers having a line to line spacing of several $\mathrm{cm}^{-1}$ ) laserline and absorption line of a given gaseous specie under investigation is an impetus for PA detection. At infrared wavelength and atmospheric pressure (typical for a PA measurement) the total width of a gas absorption line is about $2-3 \mathrm{GHz}$ (see, however [3]). For small (diatomic) molecules, probability for such spectral overlap is low. On the other hand big molecules (e.g. ethanol) are characterized by broad spectral features missing a clear and an easy to recognize fingerprint. Interference effects due to the absorption caused by other gases present in the cell, impedes performance of PA measurements to a considerable extent [4,5]. For biological studies, use of passive approaches (such as for example scrubbing and freezing) provide a remedy in combating this restriction.

Hydrocarbon compounds can be removed effectively from the streaming gaseous mixture by using 


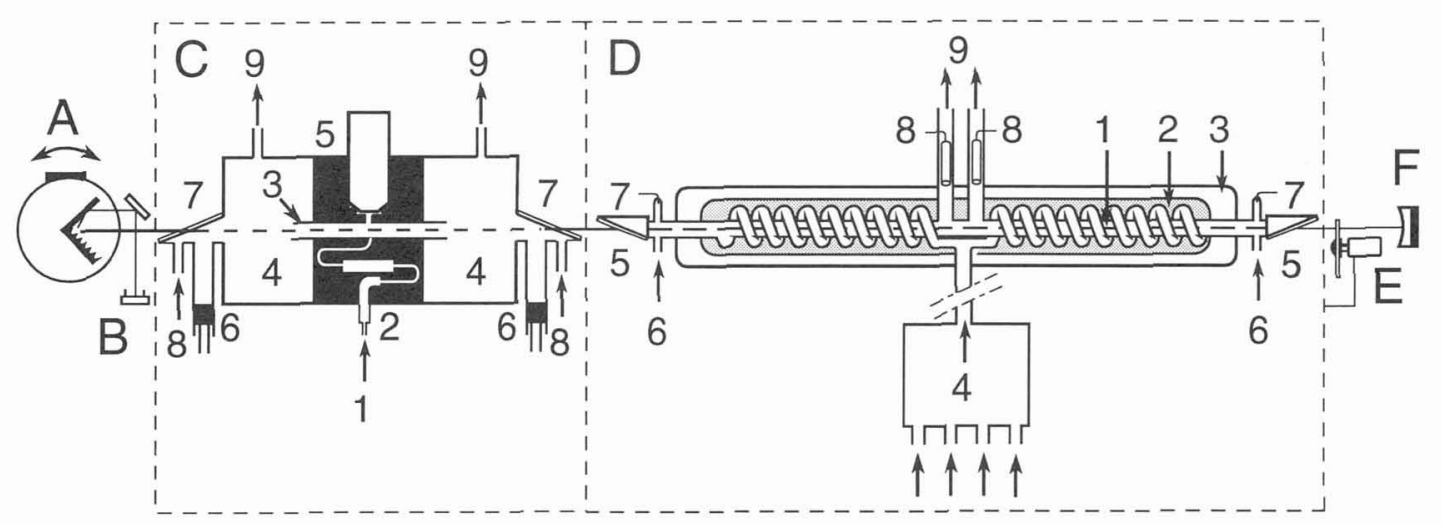

Figure 1: Experimental set-up with photoacoustic cell placed within the CO laser.

A: rotatable grating $230 \mathrm{l} / \mathrm{mm}$; B: power meter; $\mathbf{C}$ : photoacoustic cell; 1: trace gas inlet; $2: 1 / 4$ $\lambda$ noise suppression; 3: resonator; 4: buffer; 5: microphone; 6: tunable air column; 7: Brewster window; 8: buffer gas inlet; 9 : buffer gas+trace gas outlet; $\mathbf{D}$ : CO-laser;

1: laser discharge tube; 2: liquid $\mathrm{N}_{2}$ reservoir; 3: vacuum jacket; 4: gas mixture vessel $\left(\mathrm{CO}, \mathrm{N}_{2}, \mathrm{O}_{2}\right.$ and $\mathrm{He}$ ); 5: Brewster window; 6: in flux He gas; 7: Anode; 8: Cathode; 9: provision for vacuum pump; E: chopper; F: $100 \%$ reflecting mirror $\mathrm{R}=10 \mathrm{~m}$.

a high temperature $(625 \mathrm{~K})$ catalytic oxidation. Granulated potassium hydroxide (KOH) helps in eliminating the effect of $\mathrm{CO}_{2}$ residual gas. A cryogenic trap operating at $120 \mathrm{~K}$ serves to collect substantial quantities of ethanol produced in plant material under anaerobic conditions.

In this study described here we report on what is believed to be the first PA studies of $\mathrm{C}_{2} \mathrm{H}_{4}$ emission from a tomato and on the real time monitoring of $\mathrm{CH}_{4}$ gas (due to the activity of methanogenic bacteria found in anaerobic intestines) exhaled by a cockroach. Strong water vapor absorption across a large part of the $C O(\Delta v=1)$ laser emission spectrum is often annoying. However, in many biological applications fast and sensitive determination of water vapor concentration is desired. In this paper we present rapid changes of water vapor concentration due to respiration of a single cockroach.

\section{EXPERIMENTAL}

Characteristic parameters of $\mathrm{CO}_{2}[8]$ and $\mathrm{CO}$ laser (continuous wave) PA systems used in this study (with PA cell placed in intracavity configuration) are displayed in Table 1.

The $\mathrm{CO}_{2}$ laser emission covers the spectral region from 900 to $1100 \mathrm{~cm}^{-1}$ and provides some 90 laser transitions (for most abundant $\mathrm{CO}_{2}$-isotope). The liquid nitrogen cooled $\mathrm{CO}$ laser [6] emits between 1250 and $2050 \mathrm{~cm}^{-1}$, with about 300 transitions for ${ }^{12} \mathrm{C}^{16} \mathrm{O}$. The $\mathrm{CO}(\Delta \mathrm{v}=2)$ overtone version of the same laser has a comparable number of usable transitions in the range from 2400 to $3800 \mathrm{~cm}^{-1}[7]$. The operation of both systems is fully automated; measuring periods of 100 hours are typical. In order to reduce the effect of parasitic signals caused by periodic heating of Brewster windows, the PA cell is equipped with properly dimensioned buffer volumes [2] and additional $\lambda / 4$ tubes at the location of cell windows as shown in Fig. 1. The cell is designed to allow rapid removal of a gas from the central portion (resonator). The sampling gas is admitted through the port located in the middle of the resonator (flow $1 \mathrm{l} / \mathrm{h}$ ), while larger buffer volumes ( 1.5 liter each) are purged by additional dry air to improve the response time of the cell. Without this additional flow the gas will have a long residence time in the buffer volumes; due to diffusion it will re-enter the resonator. The main objective in designing the PA cell is to obtain highest possible sensitivity with a minimum loss in 


\begin{tabular}{|c|c|c|}
\hline & $\begin{array}{r}\text { Cryogenic cw CO-laser } \\
\text { liquid } \mathrm{N}_{2} \text {-cooled }\end{array}$ & $\begin{array}{r}\mathrm{cw} \text { Waveguide } \mathrm{CO}_{2} \text {-laser } \\
\text { water cooled }\end{array}$ \\
\hline $\begin{array}{l}\text { Laser configuration } \\
\text { Length of laser cavity } \\
\text { Diameter of discharge tube } \\
\text { Intracavity laser power }\end{array}$ & $\begin{array}{r}2 \mathrm{~m} \\
11.4 \mathrm{~mm} \\
1 \mathrm{~W}\left(1304.97 \mathrm{~cm}^{-1}\right) \\
40 \mathrm{~W}\left(1800 \mathrm{~cm}^{-1}\right)\end{array}$ & $\begin{array}{r}1.2 \mathrm{~m} \\
2.8 \mathrm{~mm} \\
100 \mathrm{~W}\left(949.48 \mathrm{~cm}^{-1}\right) \\
50 \mathrm{~W}\left(966.25 \mathrm{~cm}^{-1}\right)\end{array}$ \\
\hline $\begin{array}{l}\text { Photoacoustic cell configuration } \\
\text { Length of resonator } \\
\text { Diameter of resonator } \\
\text { Waist of the laser beam } \\
\text { Q-factor } \\
\text { number of microphones } \\
\text { type of microphone } \\
\text { Refilling cell volume } \\
\text { Chopping frequency } \\
\text { Minimum response time (Hlow } 1 \mathrm{l} / \mathrm{h} \text { ) } \\
\text { Sensitivity of photoacoustic cell } \\
\text { (1 Watt laser power) }\end{array}$ & $\begin{array}{r}150 \mathrm{~mm} \\
15 \mathrm{~mm} \\
4 \mathrm{~mm} \\
40 \\
1 \\
\mathrm{~B} \& \mathrm{~K} 4179 \\
26 \mathrm{ml} \\
1 \mathrm{kHz} \\
70 \mathrm{~s} \\
3 \times 10^{-9} \mathrm{~cm}^{-1}\end{array}$ & $\begin{array}{r}100 \mathrm{~mm} \\
6 \mathrm{~mm} \\
1.2 \mathrm{~mm} \\
31.8 \\
3 \\
\text { Knowles EK } 3024 \\
22 \mathrm{ml} \\
1.6 \mathrm{kHz} \\
80 \mathrm{~s} \\
\\
1.4 \times 10^{-8} \mathrm{~cm}^{-1}\end{array}$ \\
\hline $\begin{array}{l}\text { Gas: (see text) } \\
\text { Laser wavelength } \\
\text { Absorption coefficient } \\
\text { limiting sensitivity }\end{array}$ & $\begin{array}{c}\mathrm{CH}_{4} \\
1304.97 \mathrm{~cm}^{-1} \\
3 \mathrm{~atm} \mathrm{~cm}^{-1} \\
1 \mathrm{ppbv} .\end{array}$ & $\begin{array}{c}\mathrm{C}_{2} \mathrm{H}_{4} \\
949.48 \mathrm{~cm}^{-1} \\
23.7 \mathrm{~atm}^{-1} \mathrm{~cm}^{-1} \\
6 \mathrm{pptv} .\end{array}$ \\
\hline
\end{tabular}

Table 1: Technical specifications of the intracavity $\mathrm{CO}$ laser and $\mathrm{CO}_{2}$ laser sources used in photoacoustic experiments described here.

speed of response. Values quoted in Table 1 should not be considered as ultimate limits but rather as practical figures instead.

Detection limits achieved for several gases when using the $\mathrm{CO}_{2}$ laser PA spectrometer have been reported [5]. Table 2 contains detection limits attainable by the $\mathrm{CO}$ laser $(\Delta v=1)$ PA system shown in Fig. 1. Note that less favorable conditions (such as interference of water vapor) may result in performance inferior to that reported in Table 2.

\section{RESULTS AND DISCUSSION}

\subsection{Cockroaches}

Millipeds, termites, scarab beetles and cockroaches are insects accommodating methanogenic bacteria in a symbiotic fashion. The bacteria reside in the anaerobic environment of the intestinal tract and render digestible poisonous or otherwise unusable parts of the insect's food. Some insects have built-in structures in their intestines to accommodate great numbers of these microbes. Chemically, the insects obtain energy from anaerobic fermentation, with $\mathrm{H}_{2}$ as one of the fermentation products. Too high concentrations of $\mathrm{H}_{2}$ would lead to detrimental levels of proprionic acid and butyric acid; in addition, the excess energy of the reaction $\mathrm{CO}_{2}+4 \mathrm{H}_{2} \rightarrow \mathrm{CH}_{4}+2 \mathrm{H}_{2} \mathrm{O}$ would remain unused. . 


\begin{tabular}{|c|c|c|c|}
\hline gas & concentration & gas & concentration \\
\hline Methane $\mathrm{CH}_{4}$ & 1 ppbv. & Water $\mathrm{H}_{2} \mathrm{O}$ & 0.1 ppbv. \\
\hline Acetylene $\mathrm{C}_{2} \mathrm{H}_{2}$ & 1 ppbv. & Nitrous oxide $\mathrm{N}_{2} \mathrm{O}$ & 1 ppbv. \\
\hline Ethene $\mathrm{C}_{2} \mathrm{H}_{4}$ & 1 ppbv. & Nitric oxide NO & 0.3 ppbv. \\
\hline Ethane $\mathrm{C}_{2} \mathrm{H}_{6}$ & 1 ppbv. & Nitrogen dioxide $\mathrm{NO}_{2}$ & 0.1 ppbv. \\
\hline Ethanol $\mathrm{CH}_{3} \mathrm{CH}_{2} \mathrm{OH}$ & 3 ppbv. & Ammonia $\mathrm{NH}_{3}$ & 3 ppbv. \\
\hline Acetaldehyde $\mathrm{CH}_{3} \mathrm{CHO}$ & 0.1 ppbv. & Carbon dioxide $\mathrm{CO}_{2}$ & 1 ppmv. \\
\hline Pentane $\mathrm{CH}_{3}\left(\mathrm{CH}_{2}\right)_{3} \mathrm{CH}_{3}$ & 3 ppbv. & Carbon monoxide $\mathrm{CO}$ & 1 ppmv. \\
\hline Dimethyl sulfide $\left(\mathrm{CH}_{3}\right)_{2} \mathrm{~S}$ & 3 ppbv. & Sulfur dioxide $\mathrm{SO}_{2}$ & 0.1 ppbv. \\
\hline Methanethiol $\mathrm{CH}_{3} \mathrm{SH}$ & 3 ppbv. & Carbon disulfide $\mathrm{CS}_{2}$ & 0.01 ppbv. \\
\hline Trimethyl amine $\left(\mathrm{CH}_{3}\right)_{3} \mathrm{~N}$ & 1 ppbv. & Hydrogen sulfide $\mathrm{H}_{2} \mathrm{~S}$ & 0.1 ppmv. \\
\hline & & Carbonyl sulfide COS & 1 ppbv. \\
\hline
\end{tabular}

Table 2: Extrapolated detection limits (based on measured absorption strength and laser power) that can be achieved (for 21 biologically relevant gases) with the CO laser photoacoustic set-up described in Table 1.

Historically, the archae bacteria (methanogenic bacteria) or their predecessors prospered in the originally anaerobic atmosphere of the earth. After the "invention" of photosynthesis and respiration methano-bacteria withdrew into anaerobic niches, like the intestines of animals. The world-wide rate of methane production from insects amounts to some $(30$ to 300$) \times 10^{9} \mathrm{~kg} /$ year (about $20 \%$ of the total earth production).

In collaboration with dr. J. Hackstein (Dept. of Microbiology, University of Nijmegen, The Netherlands) cockroaches were chosen to study the time dependence microbiologically produced $\mathrm{CH}_{4}$ emission. To this end a single insect was placed in a measuring cuvette, a dark cell vented by air for some days. After passing through the cuvette the airflow was led along a cryo-trapping surface to remove $\mathrm{H}_{2} \mathrm{O}$ from the gas mixture before the gas was analyzed in the photoacoustic cell, utilizing the about 1 Watt intracavity laser power around $1300 \mathrm{~cm}^{-1}$.

For low methane signals, the CO-laser wavelength was switched between two neighboring transitions $\left(1308.01 \mathrm{~cm}^{-1} \mathrm{v}=33 \rightarrow 32 \mathrm{~J}=9 \rightarrow 10\right.$ and $\left.1304.97 \mathrm{~cm}^{-1} \mathrm{v}=33 \rightarrow 32 \mathrm{~J}=8 \rightarrow 9\right)$, one absorbing weakly, the other strongly. The difference signal was proportional to the $\mathrm{CH}_{4}$ concentration in the sampled air. To improve the response time of the system strong methane signals were recorded only at the CO-laserline corresponding to strongest absorption.

The Periplaneta americana (a frequently investigated cockroach, about $30 \mathrm{~mm}$ long) yielded a minimum production of less than $10 \mathrm{nmole} / \mathrm{h}$ (to be compared with the detection limit of 10 picomole $/ \mathrm{h}$ ). However, quite unexpectedly, every 15 minutes or so a peak in emission occurred, reaching values exceeding $300 \mathrm{nmole} / \mathrm{h}$ (see Fig. 2). For an air flow of $1 \mathrm{l} / \mathrm{h}$ these peak emissions correspond to easily detectable concentrations of $6 \mathrm{ppm}$.

In order to clarify the origin of these periodic methane bursts the $\mathrm{CO}_{2}$ emission was monitored simultaneously by a commercial infrared gas analyzer (URAS, Hartmann and Braun). Figure 2 displays the synchronous character of carbon dioxide and methane emissions. The conclusion, therefore, is that the methane produced by methano-bacteria in the hindgut of the cockroach near to the rectum is practically entirely emitted together with the respiratory product $\mathrm{CO}_{2}$, through the respiratory pathways. These pathways (spiracles, trachea) are normally closed (probably in order to reduce water loss) and open only periodically to release $\mathrm{CO}_{2}$ and take up $\mathrm{O}_{2}[9,10]$. 


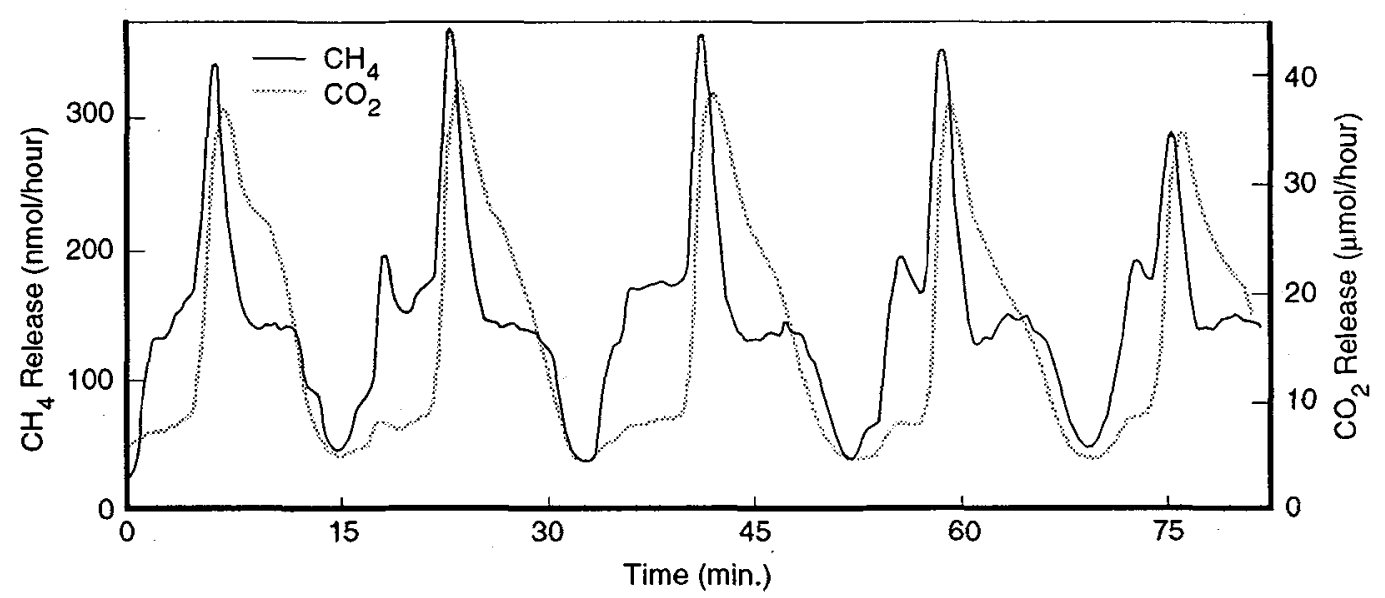

Figure 2 : The respiration of the cockroach Periplaneta americana as evidenced by the periodical $\mathrm{CO}_{2}$ emission. It is shown that the methane produced by methano-bacteria in the hindgut near to the rectum is practically entirely emitted through the respiratory pathway.

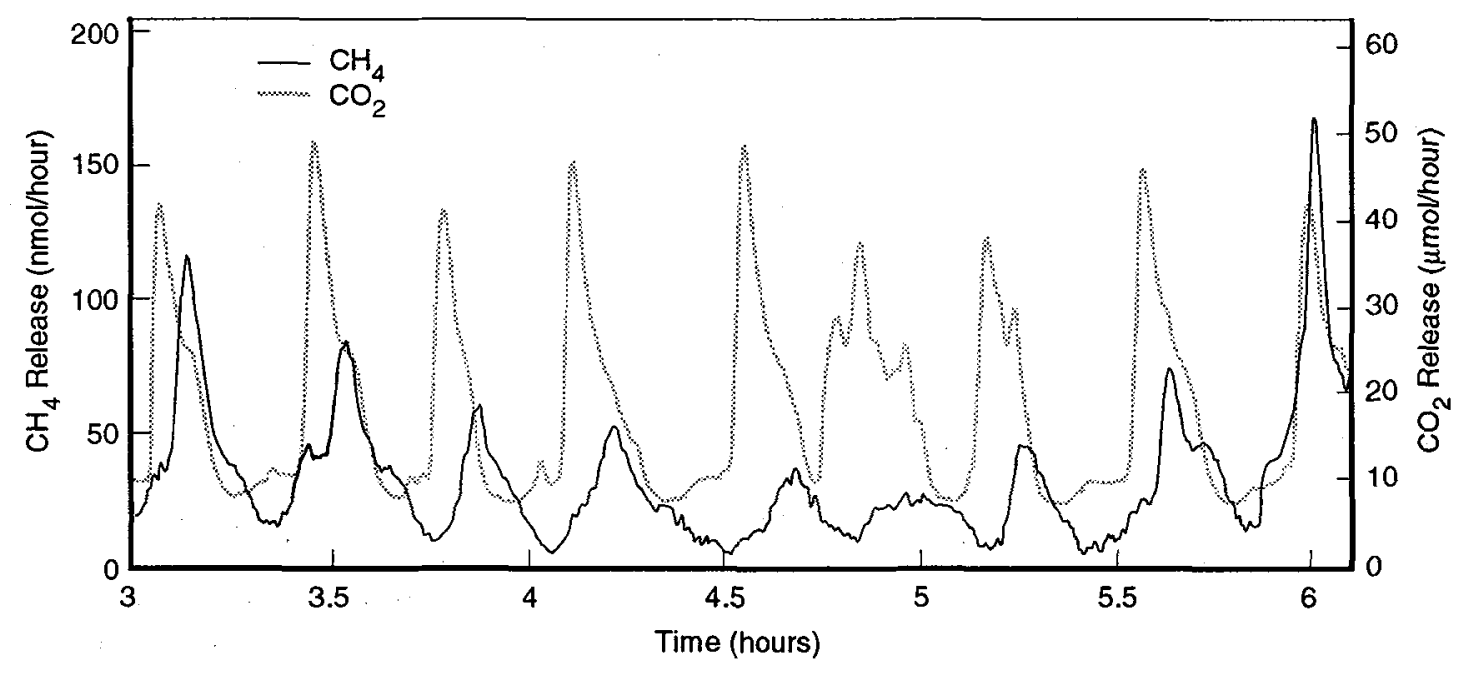

Figure 3 : The reduced methane production of the Periplaneta americana after exposure to a temporarily increased $\mathrm{CO}_{2}$ level which narcotizes the methano-bacteria. 


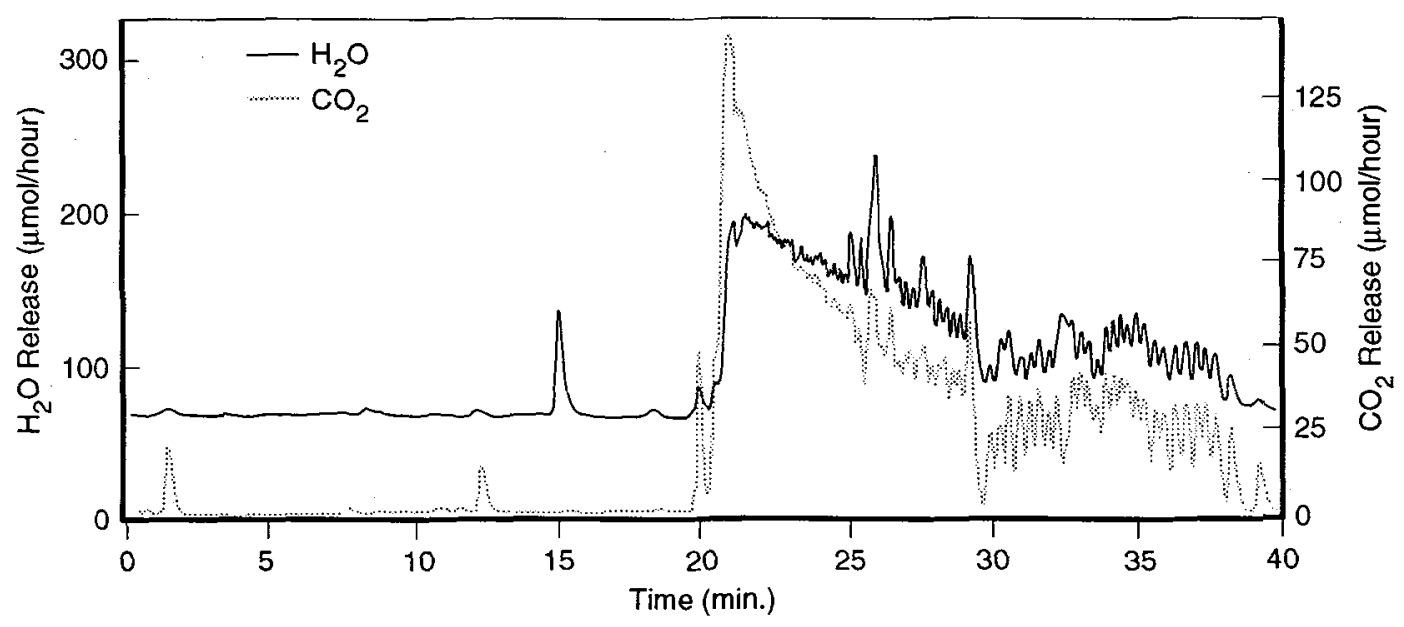

Figure 4: The respiration of the cockroach Gonfedrina with a period of 1.3 hour. Variations of the water vapor concentration are within 1 minute, reflecting pumping and venting motions of the spiracles.

Figure 3 shows the "narcotizing" effect of a temporarily increased $\mathrm{CO}_{2}$ level on the archae bacteria, yielding a substantial reduction in methane production while the respiration of the cockroach remains practically unchanged.

Especially interesting are results of Fig. 4 where the time variation of water vapor concentration can be compared to the simultaneously measured $\mathrm{CO}_{2}$ levels. These measurements were performed on a larger cockroach (Gonfedrina, $50 \mathrm{~mm}$ long, sturdier than Periplaneta americana), possessing a respiratory period of about 1.3 hour. Variations of the water vapor concentration can be seen to occur within 1 minute, reflecting pumping and venting motions of the spiracles. Note that these sensitive and fast $\mathrm{H}_{2} \mathrm{O}$ measurements were performed with the photoacoustic detector of Fig. 1, with the CO laser tuned to $1729.76 \mathrm{~cm}^{-1}(\mathrm{v}=16 \rightarrow 15 \mathrm{~J}=6 \rightarrow 7)$. The measurements demonstrate the influence of motion of the closure parts of the spiracles without leading to an effective opening. Already enlarging the intact water film covering the outlet of a spiracle, yields an increase of the water vapor concentration.

\subsection{Tomatoes}

Figure 5 features design of a double cuvette that allowed us to measure the $\mathrm{C}_{2} \mathrm{H}_{4}$ emission at different positions from a cherry tomato. In particular, emission from the calix area (where fruit is attached to the plant) can be compared to the remaining emissions integrated over the complete skin-surface. The gas is sampled alternately from the outlet at the top of the central part of the cuvette and from the outlet on the right side (Fig. 5). The $\mathrm{C}_{2} \mathrm{H}_{4}$ emission is calculated from the air flow (typically $2 \mathrm{l} / \mathrm{h}$ ) and the concentration determined from the signal detected by the photoacoustic cell. This concentration follows from the difference of signal, recorded at $\mathrm{CO}_{2}$-laser transitions at $949.48 \mathrm{~cm}^{-1}$ (10P14) and $951.19 \mathrm{~cm}^{-1}(10 \mathrm{P} 12)$. Details of photoacoustic $\mathrm{C}_{2} \mathrm{H}_{4}$ measurements are given elsewhere [8]. In addition, these local emission rates have been determined from sensitive photo deflection measurements, results which will appear in a forthcoming publication.

Tomato fruit develops from superior ovaries, i.e. what remains of sepals and petals forms the green coronet where the "berry" is attached to its plant. From the suspension area, open connections extend to the center part of the fruit; through these gas exchange with the surroundings can take place. 


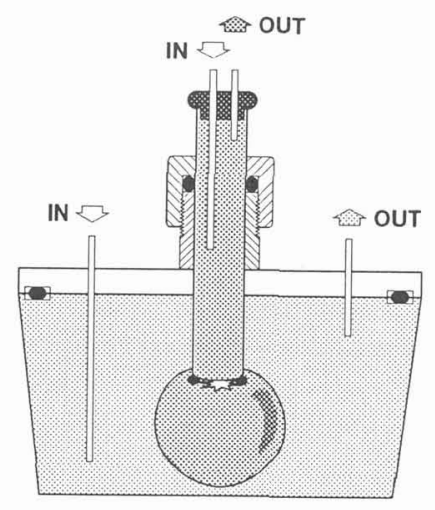

Figure 5 : Double sampling cuvette; the local production rates of the tomato are sampled by a separate airflow.

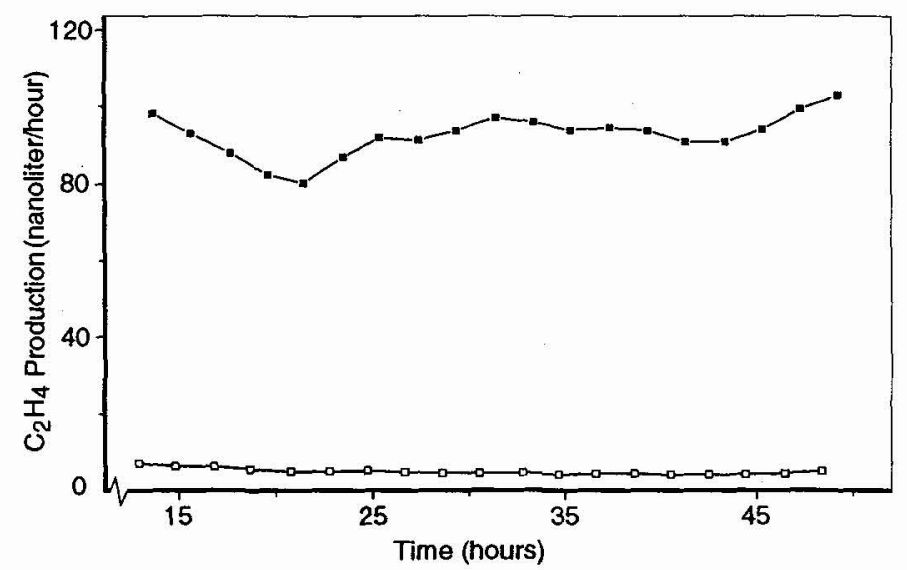

Figure $6: \mathrm{C}_{2} \mathrm{H}_{4}$ emission rates from the tomato for the coronet and the integrated skin surface

When detached from the plant tomatoes react by increasing their respiration. However, their ripening process and $\mathrm{C}_{2} \mathrm{H}_{4}$ production are not influenced [11]. If after disconnection the coronet part is removed and the appearing fresh scar sealed (e.g. using a piece of parafilm or by high vacuum grease) ripening processes are suspended and rotting occurs while the fruit remains green. In its normal ripening phase, the tomato is characterized by enhanced respiration accompanied by autocatalytic $\mathrm{C}_{2} \mathrm{H}_{4}$ production typical for climacteric fruit [12]. It is expected that gas exchange via the coronet area plays an important role under such conditions.

In Fig. 6 it is shown that $95 \%$ of emitted ethylene originates from the coronet zone, with small relative variation during the development from green/orange to red. Little is known about the overripe stage. In Fig. 7 maximum productivity amounts to about $60 \mathrm{nl} / \mathrm{h}$, shortly after the climacteric rise in ethylene production. The different maturity at time "zero" causes horizontal shifts of two production curves. The development was followed for 9 days. From the synchronous character of superimposed modulation it is clear that external factors - of presently unknown and therefore uncontrolled nature - influence the measurements. 
The effect of sealing the coronet area ( 4 hours before zero) was investigated under anoxic and aerobic conditions (Fig. 8). Opening the coronet area under anoxic conditions (at 5 hours) results in a small peak due to accumulated ethylene. Switching to aerobic conditions at 6.5 hours yields renewed ethylene production. Note that oxygen is needed for the production of ethylene. In the ethylene synthesis, starting from methionine via SAM to ACC and ending up in $\mathrm{C}_{2} \mathrm{H}_{4}$, oxygen is required for the conversion of $\mathrm{ACC}$ to $\mathrm{C}_{2} \mathrm{H}_{4}$ [13]. The shape of the curve reflects initially the ethylene production due to accumulated ACC and thereafter the restart of the ACC production. The tomato measurements form part of a collaboration with dr. E. Woltering and dr. H. van der Valk (ATO, Wageningen, The Netherlands) and demonstrate the usefulness of photoacoustic measurements in research of fruit storage. Simultaneously, other gases (like $\mathrm{CO}_{2}$ and $\mathrm{C}_{2} \mathrm{H}_{5} \mathrm{OH}$ ) were measured. Likewise specimens of other fruits, such as apple, pear, banana and fig are investigated, they exhibit quite a different behavior during ripening as will be discussed in a forthcoming publication.

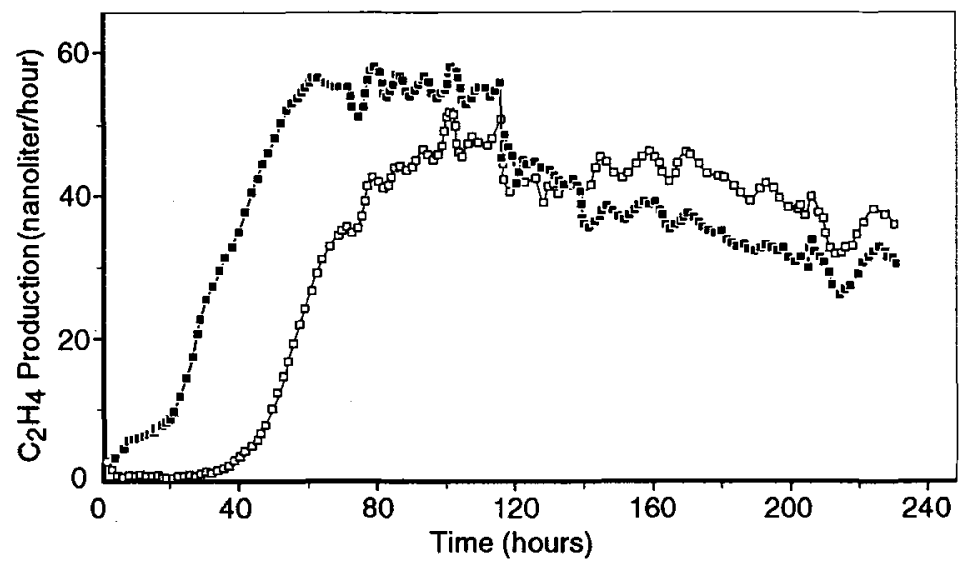

Figure 7 : Climacteric rise in $\mathrm{C}_{2} \mathrm{H}_{4}$ production of two cherry tomatoes ( $\mathrm{and}$ ) in different stages of maturation at $t=0$ hour.

\section{Acknowledgements}

This work has been supported by the European Union (Science program) and the national Dutch Technology Foundation (STW). We also like to thank Y. Wasono (Univ. of Yogyakarta,Indonesia) and C. Sikkens for their enthusiastic support. 


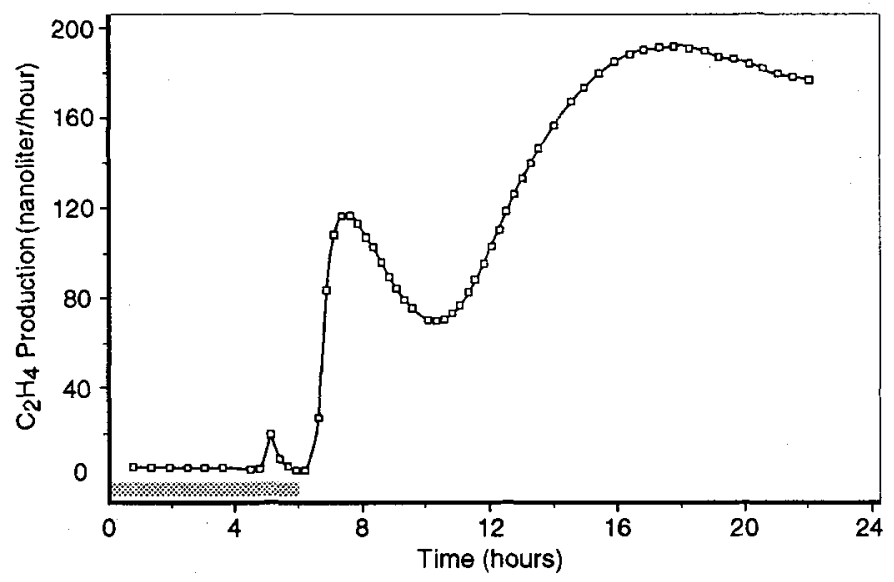

Figure 8 : Emission rates of $\mathrm{C}_{2} \mathrm{H}_{4}$ under changing conditions (anoxic at the beginning and aerobic after 6.5 hours); the coronet area was sealed for first 5 hours.

\section{References}

[1] L.A.C.J. Voesenek, M. Banga, R.H. Thier, C.M. Mudde, F.J.M. Harren, G.W.M. Barendse, C.W.P.M. Blom, Plant Physiology 103 (1993) 783-791

[2] F.G.C. Bijnen, F.J.M. Harren, J. Reuss, A.H.A.M. van Hoek, T.A. van Alen and J.H.P. Hackstein, Laser in Remote Sensing (Springer Verlag, 1994), to be published

[3] J. Henningsen, A. Olafsson and M. Hammerich, Applied Laser Spectroscopy (Plenum Press, 1990) 403-416

[4] S. Bernegger and M.W. Sigrist, Infrared Physics 30 (1990) 375-429)

[5] P.L. Meyer and M.W. Sigrist, Rev. Sci. Instr. 61 (1990) 1779-1807

[6] W. Urban; Infrared Lasers for Spectroscopy (Frontiers of Laser Spectroscopy of Gases, Kluwer Academic Publishers, 1988) 4-42

[7] E. Bachem, A. Dax, T. Fink, A. Weidenfeller, M. Schneider and W. Urban Applied Physics B 57 (1993)

[8] F.J.M. Harren, F.G.C. Bijnen, J. Reuss, L.A.C.J. Voesenek, C.W.P.M. Blom, Applied Physics $B 50$ (1990) 137-144

[9] P. Kestler, Comp. Biochem. Physiol. 100C (1991) 207-211

[10] P. Kestler, Comparative Biochemistry and Physiology of Insects (Springer Verlag, 1985) 137-183

[11] M.E. Salveit (Jr), Physiol. Plantarum 89 (1993) 204-210

[12] J.B. Biale and R.E. Young, Recent advances in the biochemistry of fruit and vegetables (Academic Press, 1981) 1-39

[13] S.F. Yang and N.E. Hoffman, Ann. Rev. Plant Physiol. 35 (1984) 155-189 